\title{
ESL Pupils' Acceptance towards Web-based Speaking Skills Resource: Sub-urban and Rural Context
}

\author{
Nurul Izzati Md Fuad, Parilah Mohd Shah, Maslawati Mohamad \\ Faculty of Education, Universiti Kebangsaan Malaysia (UKM), Malaysia \\ Received June 28, 2019; Revised September 5, 2019; Accepted September 12, 2019
}

\begin{abstract}
Copyright $\mathrm{O} 2019$ by authors, all rights reserved. Authors agree that this article remains permanently open access under
\end{abstract} the terms of the Creative Commons Attribution License 4.0 International License

\begin{abstract}
This paper presents the pupils' readiness towards the implementation of web-based speaking skills resource as a way to improve ESL pupils' speaking skills. The purpose of the study was to analyse the ESL pupils' readiness towards the implementation of web-based speaking skills resource in the sub-urban and rural settings. This study included 291 ESL pupils from sub-urban and rural schools and then utilised the web-based resource in the English lessons. The instrument was divided into six components which included (1) technology accessibility, (2) online skills and relationship, (3) motivation, (4) online discussion, (5) importance to success, and (6) problems in speaking skills to measure the ESL pupils' readiness. The findings showed high level of readiness among the ESL pupils in the sub-urban and rural context. The ESL pupils are ready to use web-based speaking skills resource to improve their speaking proficiency, however, more guidance and references should be given to ease their use. The web-based resource would change the teacher-based instructions to student-based learning which would enhance their motivation to practise conversing in English.
\end{abstract}

Keywords E-learning, Web-based Learning, Pupil Readiness, Internet

\section{Introduction}

Web-based learning is an integral part of $21^{\text {st }}$ century education since it allows the ESL pupils to use the internet to learn ubiquitously [1]. Teaching and learning has become faster and more efficient with the integration of web-based learning in English lessons. It allows the pupils and educator to connect to each other, hence encourage them to improve their proficiency through two-way communication [2]. In ESL context, the pupils are given opportunities to exchange their ideas and practice their speaking skills through the online interactions made possible by the web-based learning.

The web-based resource is used to enhance the teaching and learning as it is a student-based approach to learning rather than teacher-based [1] [3]. The teaching and learning of English speaking skills have mainly focused on classroom presentations which are time-consuming and less efficient. In the traditional classrooms, teachers are not able to give equal attention to all the ESL pupils in class hence not all are able to practice and improve their speaking skills [4]. Hence through the use of web-based learning, the ES pupils would be given equal opportunity to practise speaking skills and receive feedback from the instructor. In the Malaysian context, web-based learning provides support in learning and opportunity for the ESL pupils to learn outside of the classroom. Among the sub-urban and rural schools, web-based learning is seen as a novel effort to encourage the ESL pupils to use the internet to learn speaking skills. Despite the constraints of location and lack of fast internet connections and facilities in schools, web-based learning is still made possible through wireless handheld devices such as smartphones which are commonly used by the ESL pupils [1].

There have been few studies conducted on learner readiness in Malaysia [5][6], however these studies did not focus on web-based learning for speaking skills among ESL pupils, especially in the sub-urban and rural areas. Hence this study tries to examine the ESL pupils' readiness towards web-based learning, focusing on schools from sub-urban and rural areas in Terengganu, Malaysia.

\section{Literature Review}

\subsection{Web-based Learning}

Adeyomo et al. [7] defined web-based learning as teaching and learning through World Wide Web or the internet using computational devices and wireless network-learning. It is also interchangeably known as 
e-learning which utilises computers, laptops, smartphones, online Internet connection, online collaboration, mobile learning and virtual classrooms [1] [8]. The availability of broadband or Internet access $(3 \mathrm{G}$ or $4 \mathrm{G})$, and wi-fi networks would determine the success of web-based learning [1]. This is because e-learning can occur as long as the gadgets allows Internet connection and the use of websites or links [9]. Hence there is no more time and location boundaries in learning for through these connections, ESL pupils can collaborate, exchange information, upload and download files and create new online content [2].

\subsection{Web-based Learning in Speaking Skills}

Hedge [10] states that the teaching and learning of speaking skills should focus on the language practice in situations which mimics real life situations. It is crucial for the ESL pupils to practice real communication as they would encounter similar vocabulary and sentence structure in conversations outside of the classroom [11][12]. The web-based resource provides a supportive environment to encourage the use of real-life communication which would improve their speaking proficiency. In this study, ESL pupils were able to benefit from real-life speaking input and practice and YouTube videos available in the web-based resource. In web-based learning ESL pupils can control the pace of their learning depending on their needs and improve the current resource to suit their needs. ESL pupils have the opportunity to receive instant feedback for their questions and assessments, thus allow them to reflect and improve their performance more effectively [1]. Previous studies by Wang and Young [11][12] showed that the use of web-based resource has improved ESL learner's speaking skills.

This web-based resource also includes the use of game strategies. Young and Wang [11][12] carried out a research which integrated 'GeCALL' into their web-based resource in order to improve ESL pupils' level of vocabulary and pronunciation. ESL pupils benefit from using games in learning speaking skills as they feel less anxious to speak and practice speaking compared to speaking in class since it is just a game. Furthermore the ESL pupils will also receive feedback and response when using games hence it is suitable for practising speaking skills. The result was consistent with Chiu et al. [13] that showed that ESL pupils were more motivated and enthusiastic in practising speaking skills using game that integrated web-based resource.

\subsection{ESL Pupils Readiness in Web-based Learning}

Past studies in Malaysia have examined the learners readiness among mainly tertiary level students in public universities focusing on non-language skills [5][6]. These researches have shown that the students mainly had a high level of readiness when embarking on web-based learning.
The high level of readiness is crucial in order to ensure constant engagement in the online activities and to ensure the ESL pupils would be present throughout the whole online course or programme [5][6]. However, there is a gap between the past studies since there is a lack of studies focusing on speaking skills involving secondary schools ESL pupils in the sub-urban and rural settings.

\section{Methodology}

The purpose of this study is to investigate the ESL pupils' readiness towards the use of web-based learning in learning English speaking skills. 6 secondary schools from the sub-urban and rural areas in the Terengganu state were randomly chosen to be part of this study. The respondents were 16 years old, Form 4 ESL pupils who were following the Integrated Curriculum for Secondary Schools (KBSM) syllabus. These students were intermediate to weak learners. Overall 360 questionnaires were disseminated but only 291 were returned. The questionnaire was adapted from 1) the E-Learning Readiness by Rosenberg [14] and 2) The Online Readiness Self-Assessment Instrument by Watkins et al. [15]. It is divided into the demographic and learner readiness sections. The questionnaire used five-point Likert scale ranging from (1) strongly disagree, (2) disagree, (3) neutral, (4) agree and (5) strongly agree. The items were validated by the experts in terms of its face and content validity. Two English lecturers check items, construct, content and language validity. Pilot study was carried out using $40 \mathrm{ESL}$ pupils to determine the reliability of the items. Based on the pilot study, all items were accepted since the Cronbach Alpha value above 0.6. The researchers defined sub-urban areas as 5 kilometres from the city centre and rural areas as 10 kilometres from the city centre [16].

\section{Data Analysis and Findings}

The data was analysed using descriptive analysis of frequency, percentage and mean. Table 1 presents the descriptive result of the respondent's profiles. As reported in the table, $49.3 \%(n=143)$ were male and $50.7 \%(n=147)$ of the respondents were female. In terms of experience surfing the internet, the majority of the students use the laptop or (cromebook provided in schools) since 79.3\% $(n=230)$ stated that they have sufficient experience using the internet at laptops. Meanwhile, smartphone is the device that the least number of ESL pupils have experience using with only $33.3 \%(\mathrm{n}=96)$ having sufficient experience using it, and $5.9 \%(\mathrm{n}=17)$ stated that they have never surfed the internet using smartphones before. This shows that for the sub-urban and rural areas pupils, their dependency on the facilities provided by the schools was high. The frequency of the internet usage was analysed. And it was found that $53.8 \%$ respondents were active and very often 
used the internet, followed by $34.5 \%$ extremely often and $9.7 \%$ of the respondents in a moderate level.

Table 1. Frequency of Demographic Respondents

\begin{tabular}{|c|c|c|}
\hline Demographics & Frequency & Percentage \\
\hline \multicolumn{3}{|l|}{ Gender } \\
\hline Male & 143 & 49.3 \\
\hline Female & 147 & 50.7 \\
\hline \multicolumn{3}{|c|}{ Experience surfing the internet } \\
\hline \multicolumn{3}{|l|}{ Computer } \\
\hline No experience & 3 & 1 \\
\hline Little experience & 171 & 59 \\
\hline Sufficient experience & 114 & 39.3 \\
\hline \multicolumn{3}{|l|}{ Laptop } \\
\hline No experience & 3 & 1 \\
\hline Little experience & 56 & 19.3 \\
\hline Sufficient experience & 230 & 79.3 \\
\hline \multicolumn{3}{|l|}{ Smartphone } \\
\hline No experience & 17 & 5.9 \\
\hline Little experience & 176 & 60.7 \\
\hline Sufficient experience & 96 & 33.1 \\
\hline \multicolumn{3}{|l|}{ Internet usage } \\
\hline Slightly often & 6 & 2.1 \\
\hline Moderate & 28 & 9.7 \\
\hline Very often & 100 & 34.5 \\
\hline Extremely often & 157 & 53.8 \\
\hline
\end{tabular}

Table 2. Constructs Involved in Pupils Readiness towards the Use of Web-based Speaking Skills Resource

\begin{tabular}{|c|l|c|}
\hline No & \multicolumn{1}{|c|}{ Constructs } & Mean \\
\hline $\mathbf{1 .}$ & Technology Accessibility & 3.93 \\
\hline $\mathbf{2 .}$ & Online Skills and Relationship & 3.52 \\
\hline $\mathbf{3 .}$ & Motivation & 3.17 \\
\hline $\mathbf{4 .}$ & Online Discussion & 3.64 \\
\hline $\mathbf{5 .}$ & Importance to Success & 3.65 \\
\hline $\mathbf{6 .}$ & Problems in Speaking Skills & 2.51 \\
\hline
\end{tabular}

Table 2 shows the constructs involved in ESL pupils' readiness in using web-based learning. Technology accessibility $(\mathrm{m}=3.93)$, online skills and relationship $(\mathrm{m}=3.52)$, motivation $(\mathrm{m}=3.17)$, online discussion $(\mathrm{m}=3.64)$, importance to success $(\mathrm{m}=3.65)$ and problems in speaking skills $(\mathrm{m}=2.51)$.

\subsection{Technology Accessibility}

Table 3 illustrates that the respondents have high technology accessibility $(m=3.93)$. The respondents have access to an electronic device (ie., computer or smartphones or $\mathrm{iPad}$ ) with an Internet connection (mean=4.26), have access to a fairly new electronic device (ie. computer or smartphones or iPad with enough RAM, speakers or earphones $)(\mathrm{m}=3.84)$ and have access to electronic device (ie., computer or smartphones or iPad) with adequate software (Flash player) $(\mathrm{m}=3.70)$. These findings are similar to Syamsul et al. which show that they have sufficient access to the internet and facilities in order to use web-based learning effectively during English lessons and at home.

Table 3. Technology Accessibility

\begin{tabular}{|c|l|c|c|}
\hline No. & \multicolumn{1}{|c|}{ Item } & Mean & $\begin{array}{c}\text { Standard } \\
\text { deviation }\end{array}$ \\
\hline $\mathbf{1}$ & $\begin{array}{l}\text { I have access to an electronic } \\
\text { device (ie., computer or } \\
\text { smartphones or iPad) with an } \\
\text { Internet connection }\end{array}$ & 4.26 & .743 \\
\hline $\mathbf{2}$ & $\begin{array}{l}\text { I have access to fairly new } \\
\text { electronic device (ie. computer or } \\
\text { smartphones or iPad with enough } \\
\text { RAM, speakers or earphones). }\end{array}$ & 3.84 & .938 \\
\hline $\mathbf{3}$ & $\begin{array}{l}\text { I have access to electronic device } \\
\text { (ie., computer or smartphones or } \\
\text { iPad) with adequate software (Flash } \\
\text { player) }\end{array}$ & 3.70 & .928 \\
\hline $\mathbf{4}$ & $\begin{array}{l}\text { Overal total of Technology } \\
\text { Accessibility }\end{array}$ & 3.93 & .870 \\
\hline
\end{tabular}

\subsection{Online Skills and Relationship}

Table 4. Online Skills and Relationship

\begin{tabular}{|c|c|c|c|}
\hline No. & Item & Mean & $\begin{array}{l}\text { Standard } \\
\text { deviation }\end{array}$ \\
\hline 1 & $\begin{array}{l}\text { I have the basic skills to operate a } \\
\text { computer (e.g., saving files, } \\
\text { creating folders) }\end{array}$ & 3.95 & .887 \\
\hline 2 & $\begin{array}{l}\text { I have the basic skills for finding } \\
\text { my way around the internet (e.g., } \\
\text { using search engines and entering } \\
\text { password) }\end{array}$ & 3.82 & .875 \\
\hline 3 & $\begin{array}{l}\text { I can send an email with a file } \\
\text { attached. }\end{array}$ & 3.21 & 1.045 \\
\hline 4 & $\begin{array}{l}\text { I think that I would be comfortable } \\
\text { using a computer several times a } \\
\text { week to participate in a learning } \\
\text { activity. }\end{array}$ & 3.58 & .966 \\
\hline 5 & $\begin{array}{l}\text { I think I would be able to express } \\
\text { myself clearly through my writing } \\
\text { (e.g., mood, emotions and humour) }\end{array}$ & 3.27 & 1.037 \\
\hline 6 & $\begin{array}{l}\text { I think that I would be able to use } \\
\text { online tools (e.g., email, chat) to } \\
\text { work on assignments with pupils } \\
\text { from different time zones. }\end{array}$ & 3.38 & 1.056 \\
\hline 7 & $\begin{array}{l}\text { I think that I would be able to ask } \\
\text { questions. }\end{array}$ & 3.62 & .853 \\
\hline 8 & $\begin{array}{l}\text { I think that I would be able to make } \\
\text { comments in clear writing. }\end{array}$ & 3.35 & .853 \\
\hline & Overall total of Online Skills & 3.52 & .947 \\
\hline
\end{tabular}

The data illustrates that the ESL pupils are able to operate a computer $(\mathrm{m}=3.95)$, internet skills $(\mathrm{m}=3.82)$, frequently use $(\mathrm{m}=3.58)$, and ask questions $(\mathrm{m}=3.62)$. However the respondents also need training in terms of online skills such as sending an email with a file attached 
$(\mathrm{m}=3.21)$ and expressing themselves clearly through writing $(\mathrm{m}=3.27)$. This findings indicated the online skills is moderately important to the ESL pupils readiness $(\mathrm{m}=3.52 . \mathrm{SD}=.947)$. Although Syamsul et al. [17] findings indicated higher mean of online skills and relationship, this study focuses on secondary school pupils who are in sub-urban and rural context hence they did not receive sufficient training and opportunities to practice their online skills as compared to tertiary students.

\subsection{Motivation}

Table 5 shows that the ESL pupils motivation level is moderate at $(\mathrm{m}=3.17)$. They remain motivated to work online even without the presence of the instructor $(m=3.11)$, complete work with online distractions $(\mathrm{m}=3.02)$, and complete work with distractions at home $(\mathrm{m}=3.38)$. These findings is slightly lower than Syamsul et al. [17] study whereby the tertiary level students possessed higher level of motivation compared to the respondents since their assignments and tertiary level workload required them to use the internet often. The ESL pupils experience more teacher-based learning, and their grades are not dependent on their online performance hence contributing to moderate level of motivation.

Table 5. Motivation

\begin{tabular}{|c|c|c|c|}
\hline No. & \multicolumn{1}{|c|}{ Item } & Mean & $\begin{array}{c}\text { Standard } \\
\text { deviation }\end{array}$ \\
\hline $\mathbf{1}$ & $\begin{array}{l}\text { I think that I would be able to } \\
\text { remain motivated even though the } \\
\text { instructor is not online at all. }\end{array}$ & 3.11 & .803 \\
\hline $\mathbf{2}$ & $\begin{array}{l}\text { I think that I would be able to } \\
\text { complete my work even when there } \\
\text { are online distractions (e.g., friends } \\
\text { sending emails or Websites to surf) }\end{array}$ & 3.02 & .935 \\
\hline $\mathbf{3}$ & $\begin{array}{l}\text { I think that I would be able to } \\
\text { complete my work even when there } \\
\text { are distractions in my home }\end{array}$ & 3.38 & .926 \\
\hline & Overall total of Motivation & 3.17 & .888 \\
\hline
\end{tabular}

\subsection{Online Discussion}

Table 6 illustrates that the ESL pupils are prepared to carry out online discussions $(\mathrm{m}=3.64)$. The respondents are able to carry on a conversation using the Internet $(\mathrm{m}=3.94)$, follow online conversation $(\mathrm{m}=3.65)$, and require sufficient time to respond $(\mathrm{m}=3.57)$. However they still need guidance and require more time to have multiple conversations at the same time 'I would be comfortable having several discussions taking place in the same online chat even though I may not be participating in all of them' has only $(\mathrm{m}=3.40)$. Hence the web-based resource should provide the ESL pupils with online videos or step-by-step guide to help them conduct the online discussion successfully.
Table 6. Online Discussion

\begin{tabular}{|c|c|c|c|}
\hline No. & Item & Mean & $\begin{array}{l}\text { Standard } \\
\text { deviation }\end{array}$ \\
\hline 1 & $\begin{array}{l}\text { I think that I would be able to carry } \\
\text { on a conversation with others } \\
\text { using the Internet (e.g., Internet } \\
\text { chat or instant messenger) }\end{array}$ & 3.94 & .848 \\
\hline 2 & $\begin{array}{l}\text { I think that I would be comfortable } \\
\text { having several discussions taking } \\
\text { place in the same online chat even } \\
\text { though I may not be participating } \\
\text { in all of them. }\end{array}$ & 3.40 & 1.048 \\
\hline 3 & $\begin{array}{l}\text { I think that I would be able to } \\
\text { follow along with an online } \\
\text { conversation (e.g., internet chat, } \\
\text { instant messenger) while typing. }\end{array}$ & 3.65 & .924 \\
\hline \multirow[t]{2}{*}{4} & $\begin{array}{l}\text { I sometimes prefer to have more } \\
\text { time to prepare responses to a } \\
\text { question. }\end{array}$ & 3.57 & .879 \\
\hline & Overall total of Online Discussion & 3.64 & .924 \\
\hline
\end{tabular}

\subsection{Importance to Success}

The aspects deemed most important in terms of ensuring success in web-based learning are regular contact with the instructor $(\mathrm{m}=3.81)$ and sufficient technical support $(m=3.76)$. These findings correlates with Syamsul et al. [17] and Liu et al. [1] who state ESL pupils would benefit the most when there is two-way communication with the instructor. The ESL pupils would be able to share their concerns and opinions and at the same time receive technical support when needed. Regular contact would also encourage the pupils to use the web-based resource more often as they feel that their progress is being monitored. This would eventually enhance their performance in their speaking skills.

Table 7. Importance to Success

\begin{tabular}{|c|c|c|c|}
\hline No. & Item & Mean & $\begin{array}{l}\text { Standard } \\
\text { deviation }\end{array}$ \\
\hline 1 & $\begin{array}{l}\text { Regular contact with the instructor } \\
\text { is important to my success in online } \\
\text { learning. }\end{array}$ & 3.81 & .898 \\
\hline 2 & $\begin{array}{l}\text { Technical support is important to } \\
\text { my success in online learning }\end{array}$ & 3.76 & .805 \\
\hline 3 & $\begin{array}{l}\text { Administrative support is important } \\
\text { to my success in online learning }\end{array}$ & 3.66 & .830 \\
\hline 4 & $\begin{array}{l}\text { Frequent participation throughout } \\
\text { the learning process is important to } \\
\text { my success in online learning }\end{array}$ & 3.48 & .853 \\
\hline 5 & $\begin{array}{l}\text { I feel that prior experiences with } \\
\text { online technologies (e.g., email, } \\
\text { Internet chat) are important to my } \\
\text { success in online learning }\end{array}$ & 3.53 & .877 \\
\hline \multirow[t]{2}{*}{6} & $\begin{array}{l}\text { The ability to immediately apply } \\
\text { course materials is important to my } \\
\text { success in online learning }\end{array}$ & 3.66 & .858 \\
\hline & $\begin{array}{l}\text { Overall total of the Important } \\
\text { Aspect to Success }\end{array}$ & 3.65 & .854 \\
\hline
\end{tabular}




\subsection{Problems in Speaking Skills}

Table 8 shows that ESL pupils are facing no difficulties to introduce themselves $(\mathrm{M}=3.12)$, discuss plans $(\mathrm{M}=2.52)$, make enquiries $(\mathrm{M}=2.60)$, order goods and services $(\mathrm{M}=2.61)$. However, they have experience problems to use English verbally when solving problems ( $\mathrm{M}=2.32)$, making complaints $(\mathrm{M}=2.38)$, and responding to complaints $(\mathrm{M}=2.38)$. Hence the web-based resource developed should be able to address these topics in order to ensure that the ESL pupils would be able to benefit from it and improve their speaking skills.

Table 8. Problems in Speaking Skills

\begin{tabular}{|c|l|c|c|}
\hline No. & \multicolumn{1}{|c|}{ Item } & Mean & $\begin{array}{c}\text { Standard } \\
\text { deviation }\end{array}$ \\
\hline 1 & $\begin{array}{l}\text { I have no problem in taking part in } \\
\text { conversations in English }\end{array}$ & 2.56 & .901 \\
\hline 2 & $\begin{array}{l}\text { I have no problem to introduce } \\
\text { myself in English }\end{array}$ & 3.12 & 1.000 \\
\hline 3 & $\begin{array}{l}\text { I have no problem talking about } \\
\text { general interests in English }\end{array}$ & 2.46 & .876 \\
\hline 4 & $\begin{array}{l}\text { I have no problem in exchanging } \\
\text { information on topics of interest in } \\
\text { English }\end{array}$ & 2.41 & .824 \\
\hline 5 & $\begin{array}{l}\text { I have no problem in exchanging } \\
\text { opinion on topics of interest in } \\
\text { English }\end{array}$ & 2.38 & .808 \\
\hline 6 & $\begin{array}{l}\text { I have no problems in discussing } \\
\text { plans with other people in English }\end{array}$ & 2.52 & .799 \\
\hline 7 & $\begin{array}{l}\text { I can carry out discussion in } \\
\text { English with others in order to } \\
\text { solve problems }\end{array}$ & 2.32 & .806 \\
\hline 8 & $\begin{array}{l}\text { I have no problems expressing the } \\
\text { decisions made using English }\end{array}$ & 2.45 & .798 \\
\hline 9 & $\begin{array}{l}\text { I have no problems making } \\
\text { enquiries on an item in English }\end{array}$ & 2.60 & .880 \\
\hline 10 & $\begin{array}{l}\text { I have no problems ordering goods } \\
\text { and services in English }\end{array}$ & 2.61 & .906 \\
\hline 11 & $\begin{array}{l}\text { I have no problems making } \\
\text { complaints in English }\end{array}$ & 2.38 & .862 \\
\hline 12 & $\begin{array}{l}\text { I have no problems responding to } \\
\text { complaints in English }\end{array}$ & 2.38 & .869 \\
\hline Overall total of Problems in \\
Speaking Skills
\end{tabular}

\section{Conclusions and Implications}

Based on these findings, ESL pupils have high level of readiness for technology accessibility, while intermediate level for the other constructs which are online skills and relationship, motivation, online discussion, importance to success and problems in speaking skills. The ESL pupils' readiness is to ensure they have sufficient knowledge, enthusiasm and facilities needed to use the web-based resource effectively [17]. Since the ESL pupils from sub-urban and rural areas may not have sufficient exposure to the usage of web-based learning in speaking skills, there is a need for the instructors and web-developers to provide them with sufficient facilities, support and suitable content in order to allow the ESL pupils to benefit from the web-based learning $[6,7]$. The web-based resource would be developed to provide assistance and opportunities for the ESL pupils to enhance and practise their English speaking skills [1]. This study concludes there is a need to examine the ESL pupils' level of readiness in other settings and contexts to identify specific features that needs to be highlighted when developing a web-based resource for speaking skills. In this case, the ESL pupils are in need of content based on their syllabus that would help them to improve their skills in terms of solving problems and making and responding to complaints. Different population and level of proficiency require different approach integrated into the resource content hence there is a need to ensure the pupils are sufficiently prepared when embarking on the web-based learning [6]. Sufficient facilities, constant support from the instructor and administrator as well as online skills are important to ensure that the ESL pupils would be able to benefit from the web-based learning [5][6]. Hence, guidance and training should be provided to the ESL pupils before and while they are utilising the resource to ensure retained motivation level.

There are a few limitations to this study such as the sampling and area of research. The respondents chosen are intermediate and low level pupils from selected sub-urban and rural schools in Terengganu, Malaysia, hence the findings could not be generalized to the whole population. Furthermore, this research focused on the use of web-based learning for speaking skills hence the findings might differ among different areas of research involving e-learning. Future research could further delve into the ESL pupils' readiness towards other e-learning features such as mobile apps, virtual reality and flipped classrooms.

\section{REFERENCES}

[1] Liu SH, Lan YJ, Ho CY. Exploring the Relationship between Self-Regulated Vocabulary Learning and Web-Based Collaboration. Journal of Educational Technology \& Society. 2014 Oct 1; 17(4).

[2] Kukulska-Hulme, A. Language learning defined by time and place: A framework for next generation designs. In D'iaz V. \& Javier E. (Eds.). Left to my own devices: Learner autonomy and mobile assisted language learning 2012 6: 1-13. 2012. Bingley: United Knigdom: Emerald Group Publishing Limited.

[3] Sung HY, Hwang GJ, Chang HS. An Integrated Contextual and Web-based Issue Quest Approach to Improving Students' Learning Achievements, Attitudes and Critical Thinking. Journal of Educational Technology \& Society. 2015 Oct $1 ; 18(4)$.

[4] Wen-chi VW, Yen LL, Marek M. Using online EFL interaction to increase confidence, motivation, and ability. Journal of Educational Technology \& Society. 2011 Jul 1; 14(3): 118 .

[5] Kaur R, Sidhu G. Learner autonomy via asynchronous 
online interactions: A Malaysian perspective. International Journal of Education and Development using ICT. 2010 Oct 28; 6(3): 88-100.

[6] Tajudeen Shittu A, Madarsha Basha K, Suryani Nik AbdulRahman N, Badariah Tunku Ahmad T. Investigating students' attitude and intention to use social software in higher institution of learning in Malaysia. Multicultural Education \& Technology Journal. 2011 Aug 23; 5(3): 194-208.

[7] Adeyemo, S. A., Adedoja, G. O. \& Adelore, O. Mobile Technology: Implications of its Application on Learning. Open Praxis 2013 5(3): 249-254.

[8] Yun S, Miller PC, Baek Y, Jung J, Ko M. Improving recall and transfer skills through vocabulary building in web-based second language learning: An examination by item and feedback type. Educational Technology \& Society. 2008 Oct 1; 11(4): 158-72.

[9] Sung HY, Hwang GJ, Chang HS. An Integrated Contextual and Web-based Issue Quest Approach to Improving Students' Learning Achievements, Attitudes and Critical Thinking. Journal of Educational Technology \& Society. 2015 Oct 1 ; 18(4).

[10] Hedge, T. Teaching and learning in the language classroom. 2014 Oxford: Oxford University Press.

[11] Wang YH, Young SS. Exploring young and adult learners' perceptions of corrective feedback in ASR-based CALL system. British Journal of Educational Technology. 2012 May; 43(3): E77-80.

[12] Wang YH, Shwu-Ching Young S. A Study of the Design and Implementation of the ASR-based iCASL System with Corrective Feedback to Facilitate English Learning. Journal of Educational Technology \& Society. 2014 Apr 1; $17(2)$.

[13] Chiu YH, Kao CW, Reynolds BL. The relative effectiveness of digital game-based learning types in English as a foreign language setting: A meta-analysis. British Journal of Educational Technology. 2012 Jul; 43(4): E104-7.

[14] Rosenberg, M.J. The e-Learning readiness survey: 20 key strategic questions you and your organization must answer about the sustainability of your e-Learning efforts. 2000. McGrwHill: USA.

[15] Watkins R, Leigh D, Triner D. Assessing readiness for e-learning. Performance Improvement Quarterly. 2004 Dec; 17(4):66-79.

[16] Chien CH, Yunus MM, Mohamad M. Who We Are'in Enhancing Rural Students' English as a Second Language (ESL) Learning. American Journal of Educational Research. 2008; 1(5): 162-7.

[17] Mohamad SN, Embi MA, Nordin NM. Are students ready to adopt E-Portfolio? Social science and humanities context. Asian Social Science. 2015 May 16; 11(13): 269. 